medRxiv preprint doi: https://doi.org/10.1101/2021.01.10.21249550; this version posted January $14,2021$. The copyright holder for this preprint (which was not certified by peer review) is the author/funder, who has granted medRxiv a license to display the preprint in It is made available under a CC-BY-NC-ND 4.0 International license .

\title{
Acute Metabolic Emergencies in Diabetes and COVID-19: a systematic review and meta- analysis of case reports
}

Vasileios Papadopoulos ${ }^{1,2}$, Marios-Vasileios Koutroulos ${ }^{2}$, Dimitra-Georgia Zikoudi ${ }^{2}$, StefaniaAspasia Bakola ${ }^{2}$, Peny Avramidou ${ }^{2}$, Ntilara Touzlatzi ${ }^{2}$, Dimitrios K. Filippou ${ }^{3}$

\section{Affiliations:}

1 ENARGEIA Medical Ltd, Department of Internal Medicine, Xanthi, Greece

2 Xanthi General Hospital, Xanthi, Greece

3 Medical School, National and Kapodistrian University of Athens

\section{Corresponding author:}

Vasileios Papadopoulos, MD, PhD, BSc in Molecular Biology and Genetics

6, Elpidos str, GR 67131, Xanthi, Greece

E-mail: vaspapmd@gmail.com

Web: $\underline{\text { www.enargeia.eu }}$

\section{Running title:}

Acute Diabetes Emergencies in COVID-19

Abstract word count: 300

Manuscript word count: 2975

Conflict of interest:

None declared

NOTE: This preprint reports new research that has not been certified by peer review and should not be used to guide clinical practice. 
medRxiv preprint doi: https://doi.org/10.1101/2021.01.10.21249550; this version posted January $14,2021$. The copyright holder for this preprint (which was not certified by peer review) is the author/funder, who has granted medRxiv a license to display the preprint in It is made available under a CC-BY-NC-ND 4.0 International license.

Abstract

Background: COVID-19 is associated with DKA (Diabetic Ketoacidosis), HHS (Hyperglycaemic Hyperosmolar State) and EDKA (Euglycaemic DKA). High mortality has been observed in COVID19-related diabetic ketoacidosis; however, evidence is scarce.

Methods: A systematic literature review was conducted using EMBASE, PubMed/Medline, and Google Scholar from January to December 2020 to identify all case reports describing DKA, HHS, and EDKA, in COVID-19 patients. The Joanna Briggs Institute critical appraisal checklist for case reports was used for quality assessment. Univariate and multivariate analysis assessed correlations of study origin, combined DKA/HHS, age, BMI, HbA1c, administered antidiabetics, comorbidities, symptoms onset, disease status (DS), CRP, ferritin, d-dimers, glucose, osmolarity, $\mathrm{pH}$, bicarbonates, ketones, lactates, $\beta$-hydroxybutyric acid, anion gap, and acute kidney injury (AKI) with outcome. The relevant protocol was submitted to PROSPERO database (ID: 229356).

Results: From 312 identified publications, 41 including 71 cases analyzed qualitatively and quantitatively. The types of acute metabolic emergencies observed were DKA (45/71, 63.4\%), EDKA (6/71, 8.5\%), combined DKA/HHS (19/71, 26.8\%), and HHS (1/71, 1.4\%). Overall mortality was $32.4 \%$ (22/68 patients; 3 missing). Multivariate analysis by classical regression demonstrated that COVID-19 DS4 $\left(\mathrm{P}=3 \cdot 10^{-8}\right)$, presence of DKA/HHS $(\mathrm{P}=0.021)$, and development of AKI $(\mathrm{P}=0.037)$ were all independently correlated with death. Increased DS $(\mathrm{P}=0.003)$, elevated lactates $(\mathrm{P}<0.001)$, augmented anion gap $(\mathrm{P}<0.001)$, and presence of $\mathrm{AKI}(\mathrm{P}=0.002)$ were associated with DKA/HHS. SGLT-2i administration was linked with EDKA $(\mathrm{P}=0.004)$; however, a negative association with AKI was noted $(\mathrm{P}=0.023)$.

Conclusion: COVID-19 intertwines with acute metabolic emergencies in diabetes leading to increased mortality. Key determinants are critical COVID-19 illness, coexistence of DKA/HHS and AKI. Awareness of clinicians to timely assess them might enable early detection and immediate 
medRxiv preprint doi: https://doi.org/10.1101/2021.01.10.21249550; this version posted January $14,2021$. The copyright holder for this preprint (which was not certified by peer review) is the author/funder, who has granted medRxiv a license to display the preprint in It is made available under a CC-BY-NC-ND 4.0 International license .

treatment commencing. As previous treatment with was negatively associated with AKI, thus implying a prophylactic effect on renal function, the issue of discontinuation of SGLT-2i in COVID19 patients remains to be further evaluated.

\section{Keywords}

COVID-19, Diabetic Ketoacidosis, Hyperglycaemic Hyperosmolar State, Euglycaemic Diabetic Ketoacidosis

\section{Key messages}

\section{What is already known on this subject}

Diabetes mellitus (DM) is a risk factor for poor outcomes in COVID-19 patients.

- Diabetic ketoacidosis (DKA) and hyperglycaemic hyperosmolar state (HHS) are not rare in COVID-19 diabetic and non-diabetic patients; key determinants of outcome remain unknown.

\section{What this study adds}

- COVID-19 intertwines with acute metabolic emergencies in diabetes leading to increased mortality; key determinants are critical COVID-19 illness, coexistence of DKA and HHS as well as development of acute kidney injury.

- SGLT2-i administration is linked with euglycaemic DKA in patients with COVID-19, though preserving renal function. 
medRxiv preprint doi: https://doi.org/10.1101/2021.01.10.21249550; this version posted January $14,2021$. The copyright holder for this preprint (which was not certified by peer review) is the author/funder, who has granted medRxiv a license to display the preprint in It is made available under a CC-BY-NC-ND 4.0 International license.

\section{INTRODUCTION}

Diabetes mellitus (DM), especially type 2 diabetes mellitus (T2D), has been identified as a risk factor for poor outcomes in patients with COVID-19 caused by severe acute respiratory syndrome coronavirus 2 (SARS-CoV-2) [1,2]. COVID-19 might either induce new onset diabetes or unmask previously undiagnosed diabetes [3]. Diabetes patients have an increased risk of infection and acute respiratory distress syndrome compared with the general population and the risk is similar [4] or even greater in those with type 1 diabetes mellitus (T1D) than in T2D [5-8]; direct cytopathic effects of SARS-CoV-2 on pancreatic b-cell populations [9] as well as the over-activity of immune system might further explain COVID-19-related severe and resistant to conventional therapy DKA episodes [10]. However, whether SARS-CoV-2 directly infects b-cells in vivo through ACE2 and TMPRSS2 has been debated [11].

COVID-19 is associated with hyperglycaemic emergencies with overrepresentation of T2D in patients presenting with DKA and long-lasting ketosis $[12,13]$. DKA was the most common reason for hospitalization of T1D patients with COVID-19 [6,14]. Emergency admissions due to acute metabolic crisis in patients with diabetes remain some of the most common and challenging conditions; along with DKA, Hyperglycaemic Hyperosmolar State (HHS) and Euglycaemic DKA (EDKA) are life-threatening different entities. DKA and HHS have distinctly different pathophysiology though sharing basic management protocols. EDKA resembles DKA but without hyperglycaemia [15]. Ketoacidosis is the hallmark of DKA and is attributed to absolute insulin deficiency; therefore, it is found mostly in T1D. DKA is less commonly seen in T2D with triggers such as severe infection [16] and sodium-glucose co-transporter-2 inhibitor (SGLT-2i) therapy [17]. On the other hand, HHS is developed under insulin sufficiency, at least enough to prevent ketosis [15]. As T2D patients tend to be younger, while T1D intertwines with T2D over time in a 
medRxiv preprint doi: https://doi.org/10.1101/2021.01.10.21249550; this version posted January $14,2021$. The copyright holder for this preprint (which was not certified by peer review) is the author/funder, who has granted medRxiv a license to display the preprint in It is made available under a CC-BY-NC-ND 4.0 International license .

considerable proportion leading to double or hybrid diabetes [18], DKA is no more specific for T1D, nor HHS for T2D, as the mixed entity (HHS/DKA) is not uncommon.

Predominant features of DKA and EDKA are ketonemia and high anion gap metabolic acidosis. Both DKA and EDKA are defined as $\mathrm{pH}<7.3$ and/or bicarbonate $<15 \mathrm{mmol} / \mathrm{L}$, and detection of ketones in blood (ketonemia $>3.0 \mathrm{mmol} / \mathrm{L})$ or urine $(2+$ in urine); however, blood glucose $>11$ $\mathrm{mmol} / \mathrm{L}$ is indicative of DKA while $<11 \mathrm{mmol} / \mathrm{L}$ of EDKA. In contrast, HHS is characterized by very high glucose levels $(>33.3 \mathrm{mmol} / \mathrm{L})$ along with very high serum osmolality $(>320 \mathrm{mOsm} / \mathrm{kg})$. Several case reports concerning acute emergencies related to glucose metabolism in COVID-19 patients have been reported. Additionally, high mortality in COVID-19 and DKA has been reported [19]. A systematic review concluded that mortality rate from DKA among COVID-19 patients might approach 50\% and insisted on differentiating isolated DKA from combined DKA/HHS as the latter, which represents nearly one-fifth of the DKA cases, tends to have higher mortality than DKA alone [20]. Diabetic COVID-19 patients should be assessed for disease severity and presence of complications of diabetes, while undiagnosed diabetes should be considered, especially in patients feeling unwell [21].

The present systematic review and meta-analysis aimed to identify all case reports describing DKA, EDKA, HHS, and DKA/HHS, in patients with confirmed COVID-19 infection and provide further evidence by describing both primary (survival/discharge vs. death) and secondary (type of metabolic emergency) outcome in relation with origin, coexistence of DKA/HHS, age, body mass index (BMI), HbAlc, prior administration of antidiabetic treatment, comorbidities, days from onset of symptoms, disease status (DS), C-reactive protein (CRP), ferritin, d-dimers, glucose, osmolarity, arterial $\mathrm{pH}$, bicarbonates, ketones, lactates, $\beta$-hydroxybutyric acid $(\beta-\mathrm{HB})$, anion gap, as well as acute kidney injury $(\mathrm{AKI})$. 
medRxiv preprint doi: https://doi.org/10.1101/2021.01.10.21249550; this version posted January $14,2021$. The copyright holder for this preprint (which was not certified by peer review) is the author/funder, who has granted medRxiv a license to display the preprint in It is made available under a CC-BY-NC-ND 4.0 International license.

\section{METHODS}

\section{Literature search}

A systematic literature review was conducted using EMBASE and PubMed/Medline from January 2020 to December 2020 to identify all case reports describing DKA, EDKA, HHS, and DKA/HHS, in patients with confirmed COVID-19 infection through positive RT-PCR for SARS-CoV-2 RNA in nasopharyngeal swab or bronchoalveolar lavage, using the search strategy that included the terms (diabetes AND ketoacidosis AND covid) OR (diabetic AND ketoacidosis AND covid) OR (euglycemic AND diabetic AND ketoacidosis AND covid) OR (hyperglycaemic AND hyperosmolar AND state AND covid). Google Scholar database was used as an additional pool of published data; iterative search was performed until no additional publication could be traced. Personal communication was attempted where necessary. Unpublished dissertations and other unpublished work were scavenged. No software was used for study retrieval. The review methods were established prior to the conduct of the review. No significant deviations from the protocol were allowed. No funding was received. The relevant protocol was submitted to PROSPERO database on January 5, 2021 and corrected on January 8, 2021 (ID: 229356).

\section{Study selection}

Eligible studies were all that (1) described one or more case reports containing requested data retrievable at individual level; (2) were written in English, (3) had a consistent outcome of interest and (4) were not duplicates of older versions. No restrictions were considered regarding publication time as no outdated studies existed due to the novelty of the topic. Due to the inflated interest on publishing new works on the field, we proceeded to pre-run searches prior to the final analysis aiming to include any further studies identified. No software was used for recording decisions; all data were transformed to a Word table. Sources of financial support were traced where possible. 
medRxiv preprint doi: https://doi.org/10.1101/2021.01.10.21249550; this version posted January $14,2021$. The copyright holder for this preprint (which was not certified by peer review) is the author/funder, who has granted medRxiv a license to display the preprint in It is made available under a CC-BY-NC-ND 4.0 International license .

\section{Outcome measures}

The present study was conducted in accordance to the PRISMA statement for systematic reviews and meta-analyses [22]. Both primary (survival/discharge vs. death) and secondary (type of metabolic emergency) outcome was assessed in relation with origin, coexistence of ketotic and hyperosmotic state, age, BMI, HbAlc, prior administration of antidiabetic treatment including insulin, metformin, sulfonylureas, dipeptidyl peptidase-4 inhibitors (DPP-4i), glucagon-like peptide-1 receptor agonists (GLP-1 RAs), SGLT-2i, and pioglitazone, comorbidities including T1D/T2D, arterial hypertension, hyperlipidemia, coronary artery disease, asthma and others, days from onset of symptoms, DS (as described in the Supplemental Material), CRP, ferritin, d-dimers, glucose, osmolarity, arterial $\mathrm{pH}$, bicarbonates, ketones, lactates, $\beta$-HB, anion gap, as well as AKI. AMSTAR 2 checklist was used to assess the quality of the present study $[23,24]$.

\section{Data extraction}

A structured data collection form was used to extract all necessary data from each study: study title, first author, DKA/HHS presence, age, BMI, HbA1c, antidiabetic treatment, comorbidities, days from onset of symptoms, DS, CRP, ferritin, d-dimers, glucose, osmolarity, arterial $\mathrm{pH}$, bicarbonates, ketones, lactates, $\beta$-HB, anion gap, AKI, and outcome. AMSTAR 2 checklist was used to assess quality of the present study

\section{Quality assessment of the studies}

The Joanna Briggs Institute (JBI) critical appraisal checklist for case reports, which addresses internal validity and risk of bias of case reports designs, particularly confounding and information bias, in addition to the importance of clear reporting, was used for quality assessment [26-29]. All 
medRxiv preprint doi: https://doi.org/10.1101/2021.01.10.21249550; this version posted January 14, 2021. The copyright holder for this preprint (which was not certified by peer review) is the author/funder, who has granted medRxiv a license to display the preprint in It is made available under a CC-BY-NC-ND 4.0 International license .

studies that failed to fulfill requirements of first six questions were considered as of "suboptimal quality"; controversially, an "optimal quality" remark was given.

\section{Pattern of collaboration}

Six reviewers (V.P., M.-V.K., D.-G.Z., S.-A.B., P.A., and N.T.) performed study selection, data extraction, and quality assessment working simultaneously as three independent couples (one for screening and the other for checking decisions). These couples were blinded to each other's decisions. D.F. was responsible to dissolve any disagreement.

\section{Data synthesis and statistical analysis}

Classical regression without weighing each data point was used for data synthesis. The relevant odds ratios (OR) were used to construct a forest plot for visualization purposes using Revman 5.3 software [30]. Further details are provided in as Supplemental Material.

\section{Patient and Public Involvement Statement}

Patients and the public were not involved in any way in the present study. 
medRxiv preprint doi: https://doi.org/10.1101/2021.01.10.21249550; this version posted January $14,2021$. The copyright holder for this preprint (which was not certified by peer review) is the author/funder, who has granted medRxiv a license to display the preprint in It is made available under a CC-BY-NC-ND 4.0 International license .

\section{RESULTS}

\section{Study characteristics}

During the final pre-run search prior to the final analysis carried out on January 7, 2021, 312 potentially relevant publications were identified through a thorough search of literature; 174 in EMBASE, 138 in PubMed/Medline, while two more publications of interest were indentified through Google Scholar. No unpublished data of interest was detected. Personal contact contributed further information. Fourty-one publications referring to 71 separate case reports included in qualitative and quantitative synthesis [3, 31-70] (Figure 1). Three case reports did not refer to COVID-19 patients (Supplemental Table 1). All study characteristics are analytically presented in Table 1 . The quality of the present study was evaluated as "high" using the AMSTAR 2 checklist.

\section{Quality assessment of the studies}

Quality remarks are provided in Table 1; all details concerning quality assessment items are depicted analytically in Table 2. The inter-rater agreement between the two authors carried out the quality assessment process was high, as kappa was 0.87 (95\% CI: 0.79-0.95). There was no difference between studies of "optimal" and "suboptimal" quality regarding outcome ( $\mathrm{P}=0.756)$.

\section{Primary outcome}

The types of acute metabolic emergencies observed were DKA (45/71, 63.4\%), EDKA (6/71, 8.5\%), combined DKA/HHS (19/71, 26.8\%), and HHS (1/71, 1.4\%). Overall mortality was 32.4\% (22/68 patients; 3 missing).

Absence of combined DKA/HHS $(\mathrm{P}=0.006)$, and absence of AKI $(\mathrm{P}=0.001)$ are correlated with increased OR for survival. Among patients with T1D or T2D, administration of insulin was 
medRxiv preprint doi: https://doi.org/10.1101/2021.01.10.21249550; this version posted January $14,2021$. The copyright holder for this preprint (which was not certified by peer review) is the author/funder, who has granted medRxiv a license to display the preprint in It is made available under a CC-BY-NC-ND 4.0 International license .

associated with an increased OR of succumbing (5.99; 95\% CI: 0.48-76.9). In contrast, T2D patients who received metformin had an OR of 0.14 (95\% CI: 0.01-2.52).

BMI $(\mathrm{P}=0.071)$, new onset of diabetes, either T1D or T2D $(\mathrm{P}=0.071)$, DS $(\mathrm{P}=0.083)$, osmolarity $(\mathrm{P}=0.076), \mathrm{pH}$ value $(\mathrm{P}=0.063)$, and $\beta-\mathrm{HB}(\mathrm{P}=0.052)$ were considered needing further evaluation and thus were included in multivariate regression analysis. Detailed univariate analysis concerning correlations of patients characteristics with outcome is analytically presented at Table 3 and Figure 2. The most parsimonious multivariate model is highly significant $\left(\mathrm{P}=10^{-4}\right)$, suggesting that COVID-19 DS4 $\left(\mathrm{P}=3 \cdot 10^{-8}\right)$, presence of DKA/HHS $(\mathrm{P}=0.021)$, and development of AKI $(\mathrm{P}=0.037)$ are all independently correlated with death (Figure 3).

\section{Secondary outcome}

Increased DS ( $\mathrm{P}=0.003)$, elevated lactates $(\mathrm{P}<0.001)$, augmented anion gap $(\mathrm{P}<0.001)$, and presence of AKI $(\mathrm{P}=0.002)$ were associated with DKA/HHS.

SGLT-2i administration was linked with EDKA (Fisher's exact $\mathrm{P}=0.004$ ); however, a negative association with AKI was noted $(\mathrm{P}=0.023)$. 
medRxiv preprint doi: https://doi.org/10.1101/2021.01.10.21249550; this version posted January $14,2021$. The copyright holder for this preprint (which was not certified by peer review) is the author/funder, who has granted medRxiv a license to display the preprint in It is made available under a CC-BY-NC-ND 4.0 International license.

\section{DISCUSSION}

We describe three major determinants of outcome during acute metabolic emergencies in diabetes in COVID-19 patients: i) COVID-19 critical illness necessitating mechanical ventilation (DS4), ii) simultaneous presence of ketoacidosis and hyperosmosis as DKA/HHS ( $\mathrm{P}=0.021)$, and iii) AKI. To the best of our belief, this is the first time that prominent features that enable intertwining of COVID19 and acute metabolic emergencies in diabetes leading to increased mortality are presented in a comprehensive and justified manner.

Our study revealed an overall mortality of $32.4 \%$ (22/68 patients; 3 missing) in COVID-19 patients who had developed DKA, EDKA, DKA/HHS, and HHS. Interestingly, two recently published case series report mortality rates that range from as low as $7.7 \%(2 / 26$ patients) [12] and $1 / 7$ patients (12.9\%) [71], to $50 \%$ (25/50 patients) [19]; however, whether these case series are representative remains to be answered.

Our findings regarding the independent correlation of critical illness and mortality during COVID19-related acute metabolic emergencies in diabetes confront with what is already reported [19]. Survivors were reported to have lower CRP levels when compared with non-survivors; additionally, the former required intubation and mechanical ventilation more frequently [19].

Furthermore, we exhibited an independent correlation of AKI with mortality during COVID-19related DKA, EDkA, DKA/HHS, and HHS. AKI is quite common among patients without critical illness and usually has a mixed etiology intertwining sepsis, ischemia and nephrotoxicity and perplexing recognition and treatment [72]. AKI was observed in $92 \%(23 / 25)$ and $60 \%(15 / 25)$ of COVID-19-related DKA non-survivors and survivors, respectively; these data indicate that AKI is significantly correlated with death in patients with COVID-19-related DKA [19]. Similarly, renal replacement therapy was required in $40 \%(10 / 25)$ and $4 \%(1 / 25)$ COVID-19-related DKA non- 
medRxiv preprint doi: https://doi.org/10.1101/2021.01.10.21249550; this version posted January $14,2021$. The copyright holder for this preprint (which was not certified by peer review) is the author/funder, who has granted medRxiv a license to display the preprint in It is made available under a CC-BY-NC-ND 4.0 International license .

survivors and survivors, respectively, implying that renal replacement therapy is significantly correlated with death in these patients [19].

Additionally, we demonstrated an independent correlation of mixed DKA/HHS related to COVID-19 infection with non-surviving. Our results are in keeping with Pal et al., who describe a statistically significant difference in arterial blood $\mathrm{pH}$ between COVID-19-related DKA survivors when compared with non-survivors [20]. Despite that data linking increased osmolarity with increased fatality rate in COVID-19 patients are lacking, it is well known that death occurs in 5-16\% of patients with HHS in general, a rate that is about 10-fold higher than that reported for DKA [73-75]. Moreover, a hypertonic environment impairs the immune response, thus facilitating the development of infection [76].

We have noticed that all patients but one (a patient with gestational diabetes) who had developed EDKA received SGLT-2i treatment; however, a negative association with AKI was noted thus implying a prophylactic effect on renal function. Treatment with SGLT-2i has been reported to trigger EDKA in T2D patients with [39] or without COVID-19 infection, usually during other infections, sepsis or surgery [77-79]. These regimens might be prescribed even for T1D, even without reimbursement; interestingly, a single case report of a patient with T1D who received empagliflozin 25mg q24h and developed EDKA during COVID-19 pneumonia has been recently published [40]. Glycaemic stability can mislead the clinician, since hyperglycosuria induced by SGLT-2i may blunt hyperglycaemia during infection and contribute to a lack of insulin, finally promoting ketogenesis [77]. Therefore, it is strongly advised that the use of SGLT-2i should be discontinued at once as soon as COVID-19 is diagnosed, while the exclusive administration of insulin is considered the safest choice [79-80]. Nevertheless, our finding deserves further evaluation being in keeping with the fact that SGLT2-i administration slows the decline observed in the annual renal function in T2D patients with $\mathrm{eGFR}<60 \mathrm{ml} / \mathrm{min} / 1.73 \mathrm{~m}^{2}$, in non-COVID-19 patients [81]. 
medRxiv preprint doi: https://doi.org/10.1101/2021.01.10.21249550; this version posted January $14,2021$. The copyright holder for this preprint (which was not certified by peer review) is the author/funder, who has granted medRxiv a license to display the preprint in It is made available under a CC-BY-NC-ND 4.0 International license .

We have not detected any correlation of antidiabetic drug category other than SGLT-2i with any special type of metabolic emergency or outcome; this observation conveys the limitations of the small sample size of the present study. GLP-1 RAs reduce circulating inflammatory biomarkers in diabetic and/or obese patients while insulin reduces these biomarkers in critically ill patients. Pioglitazone was also shown to upregulate ACE2 in hepatocytes of rats fed with a high fat diet. Finally, the DPP-4 is the entry receptor of MERSCoV, raising concerns about the impact of DPP-4i during the course of coronavirus infection [82].

Interestingly, we demonstrated that insulin-treated patients presented an increased OR to succumb in contrast with those treated with metformin. Though insulin administration had been associated with poor prognosis by another group of investigators [83] it restores ACE and ACE2 serum levels, thus hypothesizing that it exerts a protective effect at least in patients that are non-insulin-depleted [84]. Therefore, this finding of ours could reflect a confounder effect due to either the type of diabetes, or increased age. T1D patients, who are by definition insulin-dependent, when compared with T2D patients, are more prone to adverse outcome during COVID-19 infection [5]; moreover, unfavorable outcome was observed more often in older patients presenting COVID-19-related DKA [19].

COVID-19 might either induce new onset diabetes or unmask previously undiagnosed T1D or T2D; elevated HbA1c values at admission confronts for the latter [3]. Both SARS and COVID-19 have been reported to trigger transient insulin resistance and hyperglycaemia. SARS results in elevated glucose during admission; however, glucose intolerance is resolved at hospital discharge [39]. SARS-CoV-2 can trigger severe diabetic ketoacidosis at presentation in individuals with new-onset diabetes despite that evidence etiologically linking SARS-CoV-2 with T1D are lacking [85]. This COVID-19 induced insulin resistance may partly explain poor responses to DKA management [39]. Emerging data indicate a bidirectional relationship between T2D and COVID-19 [86]. Impairment of innate and adaptive immunity tames the ability to fight infection in patients with diabetes and particularly in obese. Furthermore, severe COVID-19 infection significantly reduces the numbers of 
medRxiv preprint doi: https://doi.org/10.1101/2021.01.10.21249550; this version posted January $14,2021$. The copyright holder for this preprint (which was not certified by peer review) is the author/funder, who has granted medRxiv a license to display the preprint in It is made available under a CC-BY-NC-ND 4.0 International license .

natural killer cells $(\mathrm{CD} 4+/ \mathrm{CD} 8+$ cells $)$ and $\mathrm{CD} 4+/ \mathrm{CD} 8+$ lymphocytes. The association between COVID-19 and hyperglycemia in elderly patients with T2D might reflect metabolic inflammation and exaggerated cytokine release. SARS-CoV2 infection can deteriorate glycemic control by enhancing insulin resistance and impaired insulin secretion, thus leading to DKA $[10,87]$. The unique interactions between SARS-CoV-2 and the RAAS might provide yet another mechanism in the pathophysiology of DKA firstly by direct entry of SARS-CoV-2 into pancreatic islet cells worsening b-cell injury and secondly by downregulation of ACE2 after viral entry that can lead to unopposed angiotensin II and subsequent insulin secretion impedance [88]. ACE2 expression at both mRNA and protein level is increased substantially in human b-cells in response to inflammatory cytokines, presumably rendering these cells more susceptible to infection [89].

Nevertheless, rigorous and proper restoration of volume and insulin adequacy, along with potassium preservation should be commenced immediately in any case of COVID-19-related DKA. As the relationship between SARS-CoV-2 and the RAAS can complicate DKA management due to increased pulmonary vascular permeability and worsened damage to lung parenchyma, fluid replacement needs to be administered judiciously to avoid aggravating pulmonary injury. This also underlies the importance of careful assessment of fluid status through objective hemodynamic parameters to determine the amount of fluid replacement. Another important aspect in DKA management is monitoring and correcting electrolyte abnormalities. As angiotensin II stimulates aldosterone secretion and increases renal potassium loss, hypokalemia might evolve necessitating additional potassium supplementation in order to continue intravenous insulin to suppress ketogenesis [86,90-92].

A major limitation of the present study is that it relies only in case reports, which lack the ability to generalize or establish cause-effect relationship, while conveying all danger of over-interpretation, publication bias, retrospective design, and distraction of reader when focusing on the unusual. However, the major merits of case reporting focus, among other, on detecting novelties, and 
medRxiv preprint doi: https://doi.org/10.1101/2021.01.10.21249550; this version posted January 14, 2021. The copyright holder for this preprint (which was not certified by peer review) is the author/funder, who has granted medRxiv a license to display the preprint in It is made available under a CC-BY-NC-ND 4.0 International license .

generating hypotheses, which are considered absolutely necessary during the course of COVID-19 pandemic [93].

As a conclusion, COVID-19 intertwines with acute metabolic emergencies in diabetes leading to increased mortality. Key determinants are critical COVID-19 illness, coexistence of ketoacidosis and hyperosmosis and AKI and awareness of clinicians to timely assess them might enable early detection and immediate treatment commencing of DKA, EDKA, HHS and DKA/HHS in COVID19 patients. Moreover, as previous treatment with SGLT-2i demonstrated a negative association with AKI thus implying a prophylactic effect on renal function the issue of discontinuation of these regimens in COVID-19 patients remains to be further evaluated. Properly designed studies are needed to consolidate knowledge on the underlying pathophysiological mechanisms. 
medRxiv preprint doi: https://doi.org/10.1101/2021.01.10.21249550; this version posted January $14,2021$. The copyright holder for this preprint (which was not certified by peer review) is the author/funder, who has granted medRxiv a license to display the preprint in It is made available under a CC-BY-NC-ND 4.0 International license .

Contributors VP was responsible for study design, data interpretation, as well as statistical analysis and participated in study selection, data extraction, quality assessment, as well as the writing of the manuscript. MVK, DGZ, SAB, PA, NT, participated in study selection, data extraction, quality assessment, and the writing of the manuscript; DF supervised the project and helped develop the idea of the project.

Funding The authors have not declared a specific grant for this research from any funding agency in the public, commercial or not-for-profit sectors.

Competing interests None declared.

Patient consent for publication Not required.

Provenance and peer review Not commissioned; externally peer reviewed.

Data availability statement Data are available in a public, open access repository. Not applicable.

\section{ORCID iDs}

Vasileios Papadopoulos http://orcid.org/0000-0002-4188-9518

Marios-Vasileios Koutroulos http://orcid.org/0000-0002-3264-5415

Dimitra-Georgia Zikoudi http://orcid.org/0000-0002-3890-9776

Stefania-Aspasia Bakola http://orcid.org/0000-0002-6238-3161

Peny Avramidou http://orcid.org/0000-0003-2493-3596

Ntilara Touzlatzi http://orcid.org/0000-0002-3209-5927

Dimitrios K. Filippou http://orcid.org/0000-0001-5410-3046 
medRxiv preprint doi: https://doi.org/10.1101/2021.01.10.21249550; this version posted January $14,2021$. The copyright holder for this preprint (which was not certified by peer review) is the author/funder, who has granted medRxiv a license to display the preprint in It is made available under a CC-BY-NC-ND 4.0 International license .

\section{REFERENCES}

1. Zhou F, Yu T, Du R, et al. Clinical course and risk factors for mortality of adult inpatients with COVID-19 in Wuhan, China: a retrospective cohort study. Lancet. 2020 Mar 28;395(10229):1054-1062.

2. Ma WX, Ran XW. [The Management of Blood Glucose Should be Emphasized in the Treatment of COVID-19]. Sichuan Da Xue Xue Bao Yi Xue Ban. 2020 Mar;51(2):146-150.

3. Kuchay MS, Reddy PK, Gagneja S, et al. Short term follow-up of patients presenting with acute onset diabetes and diabetic ketoacidosis during an episode of COVID-19. Diabetes Metab Syndr. 2020 Oct 21;14(6):20392041.

4. Gregory JM, Slaughter JC, Duffus SH, et al. COVID-19 Severity Is Tripled in the Diabetes Community: A Prospective Analysis of the Pandemic's Impact in Type 1 and Type 2 Diabetes. Diabetes Care. 2020 Dec 2:dc202260.

5. McGurnaghan SJ, Weir A, Bishop J, et al.; Public Health Scotland COVID-19 Health Protection Study Group; Scottish Diabetes Research Network Epidemiology Group. Risks of and risk factors for COVID-19 disease in people with diabetes: a cohort study of the total population of Scotland. Lancet Diabetes Endocrinol. 2020 Dec 23:S2213-8587(20)30405-8.

6. Al Hayek AA, Robert AA, Alotaibi ZK, et al. Clinical characteristics of hospitalized and home isolated COVID-19 patients with type 1 diabetes. Diabetes Metab Syndr. 2020 Sep 10;14(6):1841-1845.

7. Chowdhury S, Goswami S. COVID-19 and type 1 diabetes: dealing with the difficult duo. Int J Diabetes Dev Ctries. 2020 Jul 14:1-6. doi: 10.1007/s13410-020-00846-Z.

8. Wu C, Chen X, Cai Y, et al. Risk Factors Associated With Acute Respiratory Distress Syndrome and Death in Patients With Coronavirus Disease 2019 Pneumonia in Wuhan, China. JAMA Intern Med. 2020 Jul $1 ; 180(7): 934-943$.

9. Yang JK, Lin SS, Ji XJ, et al. Binding of SARS coronavirus to its receptor damages islets and causes acute diabetes. Acta Diabetol. 2010 Sep;47(3):193-9.

10. Muniangi-Muhitu H, Akalestou E, Salem V, et al. Covid-19 and Diabetes: A Complex Bidirectional Relationship. Front Endocrinol (Lausanne). 2020 Oct 8;11:582936.

11. Coate KC, Cha J, Shrestha S, Wang W, et al.; HPAP Consortium, Brissova M, Powers AC. SARS-CoV-2 Cell Entry Factors ACE2 and TMPRSS2 Are Expressed in the Microvasculature and Ducts of Human Pancreas but Are Not Enriched in $\beta$ Cells. Cell Metab. 2020 Dec 1;32(6):1028-1040.e4. 
medRxiv preprint doi: https://doi.org/10.1101/2021.01.10.21249550; this version posted January $14,2021$. The copyright holder for this preprint (which was not certified by peer review) is the author/funder, who has granted medRxiv a license to display the preprint in It is made available under a CC-BY-NC-ND 4.0 International license .

12. Armeni E, Aziz U, Qamar S, et al. Protracted ketonaemia in hyperglycaemic emergencies in COVID-19: a retrospective case series. Lancet Diabetes Endocrinol. 2020 Aug;8(8):660-663.

13. Tsai PH, Lai WY, Lin YY, et al. Clinical Manifestation and Disease Progression in COVID-19 Infection. J Chin Med Assoc. 2020 Nov 19.

14. Beliard K, Ebekozien O, Demeterco-Berggren C, et al. Increased DKA at presentation among newly diagnosed type 1 diabetes patients with or without COVID-19: Data from a multi-site surveillance registry. J Diabetes. 2020 Dec 7.

15. Muneer M, Akbar I. Acute Metabolic Emergencies in Diabetes: DKA, HHS and EDKA. Adv Exp Med Biol. 2021;1307:85-114.

16. Umpierrez G, Korytkowski M. Diabetic emergencies - ketoacidosis, hyperglycaemic hyperosmolar state and hypoglycaemia. Nat Rev Endocrinol. 2016 Apr;12(4):222-32.

17. Rosenstock J, Ferrannini E. Euglycemic Diabetic Ketoacidosis: A Predictable, Detectable, and Preventable Safety Concern With SGLT2 Inhibitors. Diabetes Care. 2015 Sep;38(9):1638-42.

18. Khawandanah J. Double or hybrid diabetes: A systematic review on disease prevalence, characteristics and risk factors. Nutr Diabetes. 2019 Nov 4;9(1):33.

19. Chamorro-Pareja N, Parthasarathy S, Annam J, et al. Letter to the editor: Unexpected high mortality in COVID19 and diabetic ketoacidosis. Metabolism. 2020 Sep;110:154301.

20. Pal R, Banerjee M, Yadav U, et al. Clinical profile and outcomes in COVID-19 patients with diabetic ketoacidosis: A systematic review of literature. Diabetes Metab Syndr. 2020 Aug 18;14(6):1563-1569.

21. Fleming N, Sacks LJ, Pham C, et al. An overview of COVID-19 in people with diabetes pathophysiology and considerations in the inpatient setting. Diabet Med. 2020 Dec 29:e14509.

22. Moher D, Liberati A, Tetzlaff J, Altman DG; PRISMA Group. Preferred reporting items for systematic reviews and meta-analyses: the PRISMA statement. PLoS Med. 2009 Jul 21;6(7):e1000097.

23. Shea BJ, Reeves BC, Wells G et al. AMSTAR 2: a critical appraisal tool for systematic reviews that include randomised or non-randomised studies of healthcare interventions, or both. BMJ 2017;21:358:j4008.

24. Rainkie DC, Abedini ZS, Abdelkader NN. Reporting and methodological quality of systematic reviews and meta-analysis with protocols in Diabetes Mellitus Type II: A systematic review. PLoS One. 2020 Dec 16;15(12):e0243091.

25. Hadjadj J, Yatim N, Barnabei L, et al. Impaired type I interferon activity and inflammatory responses in severe COVID-19 patients. Science 2020;369:718-724. 
medRxiv preprint doi: https://doi.org/10.1101/2021.01.10.21249550; this version posted January $14,2021$. The copyright holder for this preprint (which was not certified by peer review) is the author/funder, who has granted medRxiv a license to display the preprint in It is made available under a CC-BY-NC-ND 4.0 International license .

26. Munn Z, Barker TH, Moola S, et al. Methodological quality of case series studies: an introduction to the JBI critical appraisal tool. JBI Database System Rev Implement Rep. 2019 Sep 23.

27. Ma LL, Wang YY, Yang ZH, et al. Methodological quality (risk of bias) assessment tools for primary and secondary medical studies: what are they and which is better? Mil Med Res. 2020 Feb 29;7(1):7.

28. Moola S, Munn Z, Tufanaru C, et al. Chapter 7: Systematic reviews of etiology and risk. In: Aromataris E, Munn Z (Editors). Joanna Briggs Institute Reviewer's Manual. The Joanna Briggs Institute, 2017. Available from https://reviewersmanual.joannabriggs.org/

29. Murad MH, Sultan S, Haffar S, et al. Methodological quality and synthesis of case series and case reports. BMJ Evid Based Med. 2018 Apr;23(2):60-63. doi: 10.1136/bmjebm-2017-110853.

30. Review Manager Web (RevMan Web). The Cochrane Collaboration, 2019. Available at revman.cochrane.org.

31. Palermo NE, Sadhu AR, McDonnell ME. Diabetic Ketoacidosis in COVID-19: Unique Concerns and Considerations. J Clin Endocrinol Metab. 2020 Aug 1;105(8):dgaa360.

32. Reddy PK, Kuchay MS, Mehta Y, et al. Diabetic ketoacidosis precipitated by COVID-19: A report of two cases and review of literature. Diabetes Metab Syndr. 2020 Sep-Oct;14(5):1459-1462.

33. Chee YJ, Ng SJH, Yeoh E. Diabetic ketoacidosis precipitated by Covid-19 in a patient with newly diagnosed diabetes mellitus. Diabetes Res Clin Pract. 2020 Jun;164:108166.

34. Li J, Wang X, Chen J, et al. COVID-19 infection may cause ketosis and ketoacidosis. Diabetes Obes Metab. 2020 Oct;22(10):1935-1941.

35. Fang J, Genco M, Caskey RN. COVID-19 Precipitating Euglycaemic Diabetic Ketoacidosis with SGLT2 Inhibitor Use. Eur J Case Rep Intern Med. 2020 Oct 26;7(11):001943.

36. Daniel S, Gadhiya B, Parikh A, et al. COVID-19 in a Child With Diabetic Ketoacidosis: An Instigator, a Deviator or a Spectator. Indian Pediatr. 2020 Oct 15;57(10):969-970.

37. Tollard C, Champenois V, Delemer B, et al. An inaugural diabetic ketoacidosis with acute pancreatitis during COVID-19. Acta Diabetol. 2020 Nov 13:1-3. doi: 10.1007/s00592-020-01624-3.

38. Chan KH, Thimmareddygari D, Ramahi A, et al. Clinical characteristics and outcome in patients with combined diabetic ketoacidosis and hyperosmolar hyperglycemic state associated with COVID-19: A retrospective, hospital-based observational case series. Diabetes Res Clin Pract. 2020 Aug;166:108279.

39. Goldman N, Fink D, Cai J, et al. High prevalence of COVID-19-associated diabetic ketoacidosis in UK secondary care. Diabetes Res Clin Pract. 2020 Aug;166:108291. 
medRxiv preprint doi: https://doi.org/10.1101/2021.01.10.21249550; this version posted January $14,2021$. The copyright holder for this preprint (which was not certified by peer review) is the author/funder, who has granted medRxiv a license to display the preprint in It is made available under a CC-BY-NC-ND 4.0 International license.

40. Oriot P, Hermans MP. Euglycemic diabetic ketoacidosis in a patient with type 1 diabetes and SARS-CoV-2 pneumonia: case report and review of the literature. Acta Clin Belg. 2020 Jun 16:1-5.

41. Meza JL, Triana A, De Avila I, et al. Diabetic Ketoacidosis Precipitated by COVID-19 in Patients Without Respiratory Symptoms: Case Reports. Cureus. 2020 Aug 25;12(8):e10031.

42. Batista DV, Vieira CAFA, Costa TA, et al. COVID-19-associated euglycemic diabetic ketoacidosis in a patient with type 2 diabetes on SGLT2 inhibitor: a case report. Diabetol Int. 2020 Oct 28:1-4.

43. Rafique S, Ahmed FW. A Case of Combined Diabetic Ketoacidosis and Hyperosmolar Hyperglycemic State in a Patient With COVID-19. Cureus. 2020 Jul 2;12(7):e8965.

44. Heaney AI, Griffin GD, Simon EL. Newly diagnosed diabetes and diabetic ketoacidosis precipitated by COVID-19 infection. Am J Emerg Med. 2020 Nov;38(11):2491.e3-2491.e4.

45. Singh S, Foster A, Khan Z, et al. COVID-19-Induced Diabetic Ketoacidosis and Acute Respiratory Distress Syndrome in an Obese 24-Year-Old Type I Diabetic. Am J Case Rep. 2020 Oct 26;21:e925586.

46. Rabizadeh S, Hajmiri M, Rajab A, Severe diabetic ketoacidosis and coronavirus disease 2019 (COVID-19) infection in a teenage patient with newly diagnosed diabetes. J Pediatr Endocrinol Metab. 2020 Sep 25;33(9):1241-1243.

47. Emara MH, Mazid U, Atta MA, et al. Ketonuria with or without ketoacidosis as the presenting manifestation of SARS-CoV-2 (COVID-19) among uncontrolled type 2 diabetic patients. Med Hypotheses. 2020 Nov;144:110226. doi: 10.1016/j.mehy.2020.110226. Epub 2020 Sep 2.

48. Kim NY, Ha E, Moon JS, et al. Acute Hyperglycemic Crises with Coronavirus Disease-19: Case Reports. Diabetes Metab J. 2020 Apr;44(2):349-353.

49. Croft A, Bucca A, Jansen JH, et al. First-time Diabetic Ketoacidosis in Type 2 Diabetics With Covid-19 Infection: A Novel Case Series. J Emerg Med. 2020 Nov;59(5):e193-e197.

50. Haider MB, Abbas F, Hafeez W. A 46-Year-Old Woman Who Presented with Diabetic Ketoacidosis and COVID-19 Pneumonia with Multiple Pulmonary Thromboemboli: A Case Report. Am J Case Rep. 2020 Jul 20;21:e925794.

51. Alsadhan I, Alruwashid S, Alhamad M, et al. Diabetic ketoacidosis precipitated by Coronavirus disease 2019 infection: Case series. Curr Ther Res Clin Exp. 2020;93:100609.

52. Cavalcanti DD, Raz E, Shapiro M, et al. Cerebral Venous Thrombosis Associated with COVID-19. AJNR Am J Neuroradiol. 2020 Aug;41(8):1370-1376. 
medRxiv preprint doi: https://doi.org/10.1101/2021.01.10.21249550; this version posted January $14,2021$. The copyright holder for this preprint (which was not certified by peer review) is the author/funder, who has granted medRxiv a license to display the preprint in It is made available under a CC-BY-NC-ND 4.0 International license.

53. Kaur P, Posimreddy S, Singh B, et al. COVID-19 Presenting as Acute Limb Ischaemia. Eur J Case Rep Intern Med. 2020 May 19;7(6):001724.

54. Hollstein T, Schulte DM, Schulz J, et al. Autoantibody-negative insulin-dependent diabetes mellitus after SARS-CoV-2 infection: a case report. Nat Metab. 2020 Oct;2(10):1021-1024.

55. Winn SP, Oo ZT, Htun NN, et al. Diabetic Ketoacidosis in Coronavirus Disease Patients With Type 2 Diabetes Mellitus. Cureus. 2020 Aug 14;12(8):e9731.

56. Siddiqui RS, Zirkiyeva M, Saliaj M. Onset of Ketosis-Prone Diabetes in the Setting of COVID-19 Infection. Cureus. 2020 Oct 3;12(10):e10779.

57. Beaupre R 2nd, Petrie C, Toledo A. Mixed Purpuric and Maculopapular Lesions in a Patient with COVID-19: A Case Report. Clin Pract Cases Emerg Med. 2020 Aug;4(3):349-351.

58. Gianniosis M, Zhang B, Choe M. Clinical dilemma of DKA and Covid-19 infection: A case report. IDCases. 2020;22:e00938.

59. Richard I, Robinson B, Dawson A, et al. An Atypical Presentation of Fulminant Myocarditis Secondary to COVID-19 Infection. Cureus. 2020 Jul 14;12(7):e9179.

60. Soliman AT, Al-Amri M, Alleethy K, et al. Newly-onset type 1 diabetes mellitus precipitated by COVID-19 in an 8-month-old infant. Acta Biomed. 2020 Jul 13;91(3).

61. Kabashneh S, Ali H, Alkassis S. Multi-Organ Failure in a Patient With Diabetes due to COVID-19 With Clear Lungs. Cureus. 2020 May 15;12(5):e8147.

62. Kulick-Soper CV, McKee JL, Wolf RL, et al. Pearls \& Oy-sters: Bilateral globus pallidus lesions in a patient with COVID-19. Neurology. 2020 Sep 8;95(10):454-457.

63. Dass B, Beck A, Holmes C, et al. Euglycemic DKA (euDKA) as a presentation of COVID-19. Clin Case Rep. 2020 Nov 20:10.1002/ccr3.3540.

64. Smati S, Mahot P, Bourdiol A, et al. Euglycaemic ketoacidosis during gestational diabetes with concomitant COVID-19 infection. Diabetes Metab. 2020 Jul 29:S1262-3636(20)30100-2.

65. Concepción Zavaleta MJ, Armas Flórez CD, Plasencia Dueñas EA, et al. Diabetic ketoacidosis during COVID19 pandemic in a developing country. Diabetes Res Clin Pract. 2020 Oct;168:108391.

66. Cline TE, Sangha N. The case of a 69-year-old man with COVID-19 and encephalopathy. Ann Clin Transl Neurol. 2020 Nov 17:10.1002/acn3.51250.

67. Raghunandan S, Josephson CD, Verkerke H, et al. Complement inhibition in Severe COVID-19 Acute Respiratory Distress Syndrome. Front Pediatr 2020;8:895. 
medRxiv preprint doi: https://doi.org/10.1101/2021.01.10.21249550; this version posted January $14,2021$. The copyright holder for this preprint (which was not certified by peer review) is the author/funder, who has granted medRxiv a license to display the preprint in It is made available under a CC-BY-NC-ND 4.0 International license.

68. Panjawatanan P, Jha S, Hughes J, et al. A Case of Concomitant COVID-19 Infection-Induced Acute Respiratory Distress Syndrome and Diabetic Ketoacidosis: Another Challenge in Fluid Management. Cureus. 2020 Nov 30;12(11):e11805.

69. Xu C, Zia U. Recovery From Acute Kidney Injury With Diabetic Ketoacidosis Following SARS-CoV-2 Infection: A Case Report and Literature Review. Cureus. 2020 Nov 25;12(11):e11702.

70. Kayina CA, Maitra S, Anand RK, et al. SARS-CoV-2 Infection Presenting with Hyperglycemia and Ketosis: A Case Series of Three Diabetic Patients. Indian J Crit Care Med. 2020 Nov;24(11):1141-1142.

71. Alkundi A, Mahmoud I, Musa A, Clinical characteristics and outcomes of COVID-19 hospitalized patients with diabetes in the United Kingdom: A retrospective single centre study. Diabetes Res Clin Pract. 2020 Jul;165:108263.

72. Makris K, Spanou L. Acute Kidney Injury: Definition, Pathophysiology and Clinical Phenotypes. Clin Biochem Rev. 2016 May;37(2):85-98.

73. Pasquel FJ, Umpierrez GE. Hyperosmolar hyperglycemic state: a historic review of the clinical presentation, diagnosis, and treatment. Diabetes Care. 2014 Nov;37(11):3124-31.

74. Bhowmick SK, Levens KL, Rettig KR. Hyperosmolar hyperglycemic crisis: an acute life-threatening event in children and adolescents with type 2 diabetes mellitus. Endocr Pract. 2005 Jan-Feb;11(1):23-9.

75. Fadini GP, de Kreutzenberg SV, Rigato M, et al. Characteristics and outcomes of the hyperglycemic hyperosmolar non-ketotic syndrome in a cohort of 51 consecutive cases at a single center. Diabetes Res Clin Pract. 2011 Nov;94(2):172-9.

76. Lang KS, Weigert C, Braedel S, et al. Inhibition of interferon-gamma expression by osmotic shrinkage of peripheral blood lymphocytes. Am J Physiol Cell Physiol. 2003 Jan;284(1):C200-8.

77. Menghoum N, Oriot P, Hermans MP, et al. Cétose ou acidocétose diabétique euglycémique chez des patients diabétiques de type 2 traités par inhibiteurs du SGLT2: une série de cas cliniques en Belgique [Diabetic euglycemic ketosis or ketoacidosis in individuals with type 2 diabetes treated by SGLT2 inhibitors: A series of Belgian clinical cases]. Rev Med Interne. 2020 Apr;41(4):226-231.

78. Ozer O, Yorulmaz G. Euglycemic Diabetic Ketoacidosis Associated with Empagliflozin Use in the Course of the SARS-Cov-2 Pandemic. J Coll Physicians Surg Pak. 2020 Oct;30(10):110-111.

79. Milder TY, Stocker SL, Day RO, et al. Potential Safety Issues with Use of Sodium-Glucose Cotransporter 2 Inhibitors, Particularly in People with Type 2 Diabetes and Chronic Kidney Disease. Drug Saf. 2020 Dec;43(12):1211-1221. 
medRxiv preprint doi: https://doi.org/10.1101/2021.01.10.21249550; this version posted January $14,2021$. The copyright holder for this preprint (which was not certified by peer review) is the author/funder, who has granted medRxiv a license to display the preprint in It is made available under a CC-BY-NC-ND 4.0 International license.

80. Koufakis T, Metallidis S, Zebekakis P, et al. Sodium-Glucose Cotransporter 2 Inhibitors in the Era of COVID19 Pandemic: Is the Benefit to Risk Ratio Still Favorable? J Diabetes Sci Technol. 2020 Jul;14(4):745-747.

81. Hirai T, Kitada M, Monno et al. SGLT2 inhibitors in type 2 diabetic patients with renal function impairment slows the annual renal function decline, in a real clinical practice. J Diabetes Investig. 2021 Jan 8.

82. Orioli L, Hermans MP, Thissen JP, et al. COVID-19 in diabetic patients: Related risks and specifics of management. Ann Endocrinol (Paris). 2020 Jun;81(2-3):101-109.

83. Chen Y, Yang D, Cheng B, et al. Clinical Characteristics and Outcomes of Patients With Diabetes and COVID19 in Association With Glucose-Lowering Medication. Diabetes Care. 2020 Jul;43(7):1399-1407.

84. Roca-Ho H, Riera M, Palau V, et al. Characterization of ACE and ACE2 Expression within Different Organs of the NOD Mouse. Int J Mol Sci. 2017 Mar 5;18(3):563.

85. Boddu SK, Aurangabadkar G, Kuchay MS. New onset diabetes, type 1 diabetes and COVID-19. Diabetes Metab Syndr. 2020 Nov-Dec;14(6):2211-2217.

86. Apicella M, Campopiano MC, Mantuano M, et al. COVID-19 in people with diabetes: understanding the reasons for worse outcomes. Lancet Diabetes Endocrinol. 2020 Sep;8(9):782-792.

87. Sandooja R, Vura NVRK, Morocco M. Heightened ACE Activity and Unfavorable Consequences in COVID-19 Diabetic Subjects. Int J Endocrinol. 2020 Jul 16;2020:7847526.

88. Chee YJ, Tan SK, Yeoh E. Dissecting the interaction between COVID-19 and diabetes mellitus. J Diabetes Investig. 2020 Sep;11(5):1104-1114.

89. Fignani D, Licata G, Brusco N, et al. SARS-CoV-2 Receptor Angiotensin I-Converting Enzyme Type 2 (ACE2) Is Expressed in Human Pancreatic $\beta$-Cells and in the Human Pancreas Microvasculature. Front Endocrinol (Lausanne). 2020 Nov 13;11:596898.

90. Rayman G, Lumb A, Kennon B, et al. Guidance on the management of Diabetic Ketoacidosis in the exceptional circumstances of the COVID-19 pandemic. Diabet Med. 2020 Jul;37(7):1214-1216.

91. Bornstein SR, Rubino F, Khunti K, et al. Practical recommendations for the management of diabetes in patients with COVID-19. Lancet Diabetes Endocrinol. 2020 Jun;8(6):546-550.

92. Priyambada L, Wolfsdorf JI, Brink SJ, et al. ISPAD Clinical Practice Consensus Guideline: Diabetic ketoacidosis in the time of COVID-19 and resource-limited settings-role of subcutaneous insulin. Pediatr Diabetes. 2020 Dec;21(8):1394-1402.

93. Nissen T, Wynn R. The clinical case report: a review of its merits and limitations. BMC Res Notes. 2014 Apr 23;7:264. doi: 10.1186/1756-0500-7-264. 
medRxiv preprint doi: https://doi.org/10.1101/2021.01.10.21249550; this version posted January 14, 2021. The copyright holder for this

preprint (which was not certified by peer review) is the author/funder, who has granted medRxiv a license to display the preprint in

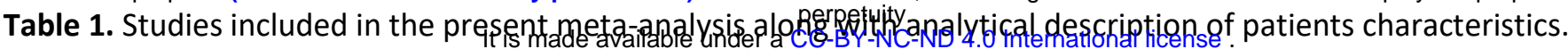

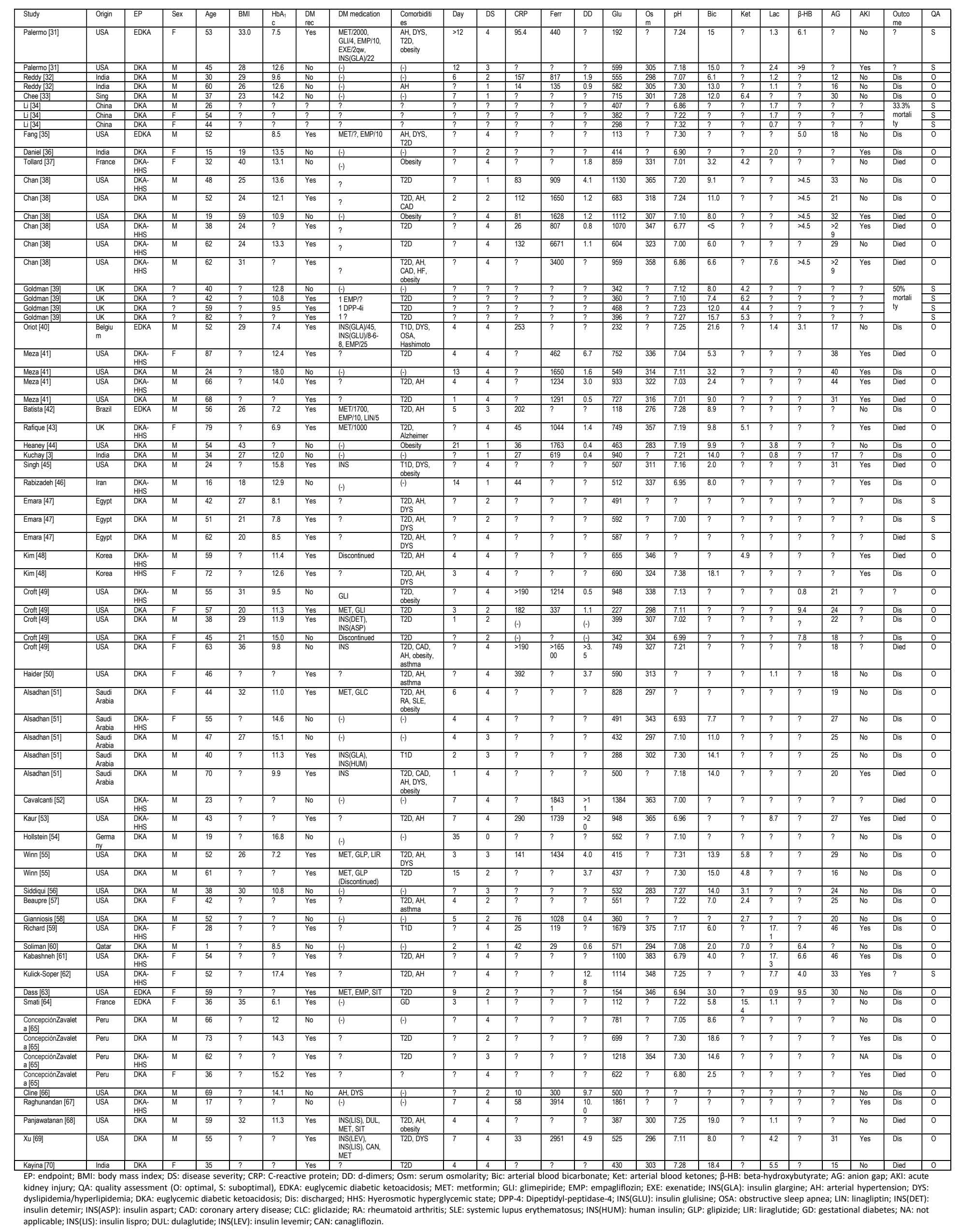


medRxiv preprint doi: https://doi.org/10.1101/2021.01.10.21249550; this version posted January 14, 2021. The copyright holder for this preprint (which was not certified by peer review) is the author/funder, who has granted medRxiv a license to display the preprint in

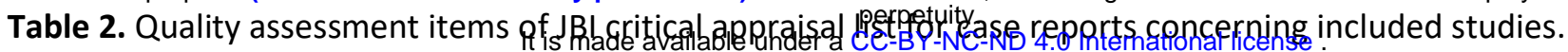

\begin{tabular}{|c|c|c|c|c|c|c|c|c|c|}
\hline Study & $\begin{array}{l}\text { Were patient's } \\
\text { demographic } \\
\text { characteristics clearly } \\
\text { described? }\end{array}$ & $\begin{array}{l}\text { Was the patient's } \\
\text { history clearly } \\
\text { described and } \\
\text { presented as a } \\
\text { timeline? }\end{array}$ & $\begin{array}{l}\text { Was the current } \\
\text { clinical condition of the } \\
\text { patient on presentation } \\
\text { clearly described? }\end{array}$ & $\begin{array}{l}\text { Were diagnostic tests } \\
\text { or assessment } \\
\text { methods and the } \\
\text { results clearly } \\
\text { described? }\end{array}$ & $\begin{array}{l}\text { Was the } \\
\text { intervention(s) or } \\
\text { treatment procedure(s) } \\
\text { clearly described? }\end{array}$ & $\begin{array}{l}\text { Was the post- } \\
\text { intervention clinical } \\
\text { condition clearly } \\
\text { described? }\end{array}$ & $\begin{array}{l}\text { Were adverse events } \\
\text { (harms) or } \\
\text { unanticipated events } \\
\text { identified and } \\
\text { described? }\end{array}$ & $\begin{array}{l}\text { Does the case report } \\
\text { provide takeaway } \\
\text { lessons? }\end{array}$ & Optimal quality \\
\hline Palermo & Yes & $U$ & Yes & Yes & $U$ & No & U & Yes & No \\
\hline Reddy & Yes & Yes & Yes & Yes & Yes & Yes & No & Yes & Yes \\
\hline Chee & Yes & Yes & Yes & Yes & Yes & $U$ & No & Yes & Yes \\
\hline $\mathrm{Li}$ & Yes & Yes & Yes & Yes & No & No & No & Yes & No \\
\hline Fang & Yes & Yes & Yes & Yes & Yes & Yes & Yes & Yes & Yes \\
\hline Daniel & Yes & U & Yes & Yes & Yes & Yes & No & Yes & Yes \\
\hline Tollard & Yes & Yes & Yes & Yes & Yes & Yes & No & Yes & Yes \\
\hline Chan & Yes & Yes & Yes & Yes & Yes & Yes & No & Yes & Yes \\
\hline Goldman & No & Yes & Yes & Yes & U & No & No & Yes & No \\
\hline Oriot & Yes & Yes & Yes & Yes & Yes & Yes & U & Yes & Yes \\
\hline Meza & Yes & Yes & Yes & Yes & Yes & Yes & No & Yes & Yes \\
\hline Batista & Yes & Yes & Yes & Yes & Yes & Yes & U & Yes & Yes \\
\hline Rafique & Yes & Yes & Yes & Yes & Yes & Yes & No & Yes & Yes \\
\hline Heaney & Yes & Yes & Yes & Yes & Yes & Yes & No & Yes & Yes \\
\hline Kuchay & Yes & Yes & Yes & Yes & Yes & Yes & No & Yes & Yes \\
\hline Singh & Yes & Yes & Yes & Yes & Yes & Yes & U & Yes & Yes \\
\hline Rabizadeh & Yes & Yes & Yes & Yes & Yes & Yes & No & Yes & Yes \\
\hline Emara & Yes & Yes & Yes & Yes & No & Yes & No & Yes & No \\
\hline Kim & Yes & Yes & Yes & Yes & Yes & Yes & No & Yes & Yes \\
\hline Croft & Yes & Yes & Yes & Yes & U & U & No & Yes & Yes \\
\hline Haider & Yes & Yes & Yes & Yes & Yes & Yes & No & Yes & Yes \\
\hline Alsadhan & Yes & Yes & Yes & Yes & Yes & Yes & No & Yes & Yes \\
\hline Cavalcanti & Yes & Yes & Yes & Yes & U & Yes & No & Yes & Yes \\
\hline Kaur & Yes & Yes & Yes & Yes & Yes & Yes & No & Yes & Yes \\
\hline Hollstein & Yes & Yes & Yes & Yes & Yes & Yes & No & Yes & Yes \\
\hline Winn & Yes & Yes & Yes & Yes & Yes & Yes & No & Yes & Yes \\
\hline Siddiqui & Yes & Yes & Yes & Yes & Yes & Yes & No & Yes & Yes \\
\hline Beaupre & Yes & Yes & Yes & Yes & Yes & Yes & No & Yes & Yes \\
\hline Gianniosis & Yes & Yes & Yes & Yes & Yes & Yes & No & Yes & Yes \\
\hline Richard & Yes & Yes & Yes & Yes & Yes & Yes & No & Yes & Yes \\
\hline Soliman & Yes & Yes & Yes & Yes & Yes & Yes & No & Yes & Yes \\
\hline Kabashneh & Yes & Yes & Yes & Yes & Yes & Yes & No & Yes & Yes \\
\hline Kulick-Soper & Yes & Yes & Yes & Yes & U & No & No & Yes & No \\
\hline Dass & Yes & Yes & Yes & Yes & Yes & Yes & Yes & Yes & Yes \\
\hline Smati & Yes & Yes & Yes & Yes & Yes & Yes & No & Yes & Yes \\
\hline Zavaleta & Yes & Yes & Yes & Yes & Yes & $U$ & No & Yes & Yes \\
\hline Cline & Yes & Yes & Yes & Yes & Yes & Yes & No & Yes & Yes \\
\hline Raghunandan & Yes & Yes & Yes & Yes & Yes & Yes & Yes & Yes & Yes \\
\hline Panjawatanan & Yes & Yes & Yes & Yes & Yes & Yes & No & Yes & Yes \\
\hline$X u$ & Yes & Yes & Yes & Yes & Yes & Yes & No & Yes & Yes \\
\hline Kayina & Yes & Yes & Yes & Yes & Yes & Yes & No & Yes & Yes \\
\hline
\end{tabular}

\begin{tabular}{|l|l|l|l}
\hline Kayina & Yes \\
\hline Y: Yes; N: No; U: Unclear
\end{tabular} 
medRxiv preprint doi: https://doi.org/10.1101/2021.01.10.21249550; this version posted January 14, 2021. The copyright holder for this preprint (which was not certified by peer review) is the author/funder, who has granted medRxiv a license to display the preprint in

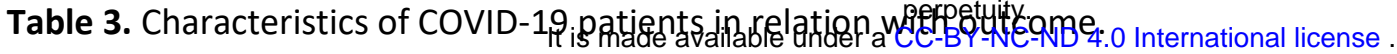

\begin{tabular}{|c|c|c|c|c|}
\hline Parameters & $\mathbf{N}$ & Mean $( \pm 95 \% \mathrm{Cl}) \dagger, \mathrm{n} \ddagger$ & $\begin{array}{l}\text { Univariate analysis } \\
\text { OR }[95 \% \mathrm{Cl}] \text { for death }\end{array}$ & $\begin{array}{c}\text { Univariate analysis } P \\
\text { ( } P \text { after } 1000 x \\
\text { bootstrapping) }\end{array}$ \\
\hline \multicolumn{5}{|l|}{ Survivors } \\
\hline $\begin{array}{l}\text { Yes } \\
\text { No }\end{array}$ & 68 & $\begin{array}{l}46 \\
22\end{array}$ & NA & NA \\
\hline \multicolumn{5}{|l|}{ Type of acute metabolic emergency } \\
\hline $\begin{array}{c}\text { DKA } \\
\text { EDKA } \\
\text { DKA/HHS } \\
\text { HHS }\end{array}$ & 71 & $\begin{array}{c}45 \\
6 \\
19 \\
1\end{array}$ & NA & NA \\
\hline \multicolumn{5}{|l|}{ USA Origin } \\
\hline $\begin{array}{c}\text { USA } \\
\text { Other countries (except USA) }\end{array}$ & 71 & $\begin{array}{l}36 \\
35\end{array}$ & $1.71[0.56-5.21]$ & $0.342(0.335)$ \\
\hline \multicolumn{5}{|l|}{ Combined DKA/HHS } \\
\hline $\begin{array}{l}\text { Yes } \\
\text { No }\end{array}$ & 71 & $\begin{array}{l}19 \\
52\end{array}$ & $4.72[1.44-15.44]$ & $0.004(0.006)$ \\
\hline $\begin{array}{l}\text { Yes } \\
\text { No }\end{array}$ & 67 & $\begin{array}{l}45 \\
22\end{array}$ & $0.97[0.30-3.33]$ & $0.961(0.955)$ \\
\hline \multicolumn{5}{|l|}{ Age } \\
\hline Mean $( \pm 95 \mathrm{Cl})$ & 67 & $47.8[43.8-51.8]$ & $1.39[0.97-2.00]$ per 10 increment & $0.073(0.120)$ \\
\hline \multicolumn{5}{|l|}{ BMI } \\
\hline Mean $( \pm 95 \mathrm{Cl})$ & 32 & $28.6[25.8-31.4]$ & $1.65[0.92-2.97]$ per 5 increment & $0.096(0.071)$ \\
\hline \multicolumn{5}{|l|}{ HbA1c } \\
\hline Mean $( \pm 95 \mathrm{Cl})$ & 50 & $11.7[10.9-12.5]$ & $1.02[0.82-1.26]$ & $0.891(0.868)$ \\
\hline \multicolumn{5}{|l|}{ New onset T1D/T2D } \\
\hline $\begin{array}{l}\text { Yes } \\
\text { No }\end{array}$ & 68 & $\begin{array}{l}25 \\
43\end{array}$ & $0.36[0.10-1.25]$ & $0.108(0.071)$ \\
\hline \multicolumn{5}{|l|}{ Previous insulin treatment } \\
\hline $\begin{array}{l}\text { Yes } \\
\text { No }\end{array}$ & 17 & $\begin{array}{l}9 \\
8\end{array}$ & $5.99[0.48-76.9] *$ & $0.165(0.071)$ \\
\hline \multicolumn{5}{|l|}{ Previous metformin treatment } \\
\hline $\begin{array}{l}\text { Yes } \\
\text { No }\end{array}$ & 18 & $\begin{array}{c}10 \\
8\end{array}$ & $0.14[0.01-2.52] * * *$ & $0.184(0.036)$ \\
\hline \multicolumn{5}{|l|}{ Comorbidity number } \\
\hline Mean $( \pm 95 \mathrm{Cl})$ & 55 & $1.8[1.5-2.2]$ & $1.34[0.86-2.09]$ per unit & $0.203(0.171)$ \\
\hline \multicolumn{5}{|l|}{ Day from onset of symptoms } \\
\hline Mean $( \pm 95 \mathrm{Cl})$ & 64 & $6.6[4.5-8.7]$ & $1.22[0.83-1.80]$ per unit & $0.302(0.203)$ \\
\hline \multicolumn{5}{|l|}{ Disease status } \\
\hline Mean $( \pm 95 \mathrm{Cl})$ & 64 & $3.0[2.7-3.3]$ & $1.20[0.90-1.60]$ per unit & $0.207(0.083)$ \\
\hline \multicolumn{5}{|l|}{ CRP } \\
\hline Mean $( \pm 95 \mathrm{Cl})$ & 26 & $123[76-150]$ & $1.60[0.51-3.11]$ per 100 increment & $0.626(0.653)$ \\
\hline \multicolumn{5}{|l|}{ Ferritin } \\
\hline Mean $( \pm 95 \mathrm{Cl})$ & 27 & 2075 [735-3410] & $1.54[0.80-2.94]$ per 1000 increment & $0.179(0.123)$ \\
\hline \multicolumn{5}{|l|}{ D-dimers } \\
\hline Mean $( \pm 95 \mathrm{Cl})$ & 29 & $3.9[2.2-5.7]$ & $1.05[0.89-1.23]$ per unit & $0.581(0.595)$ \\
\hline \multicolumn{5}{|l|}{ Glucose } \\
\hline Mean $( \pm 95 \mathrm{Cl})$ & 71 & $626[547-705]$ & 1.14 [0.97-1.33] per 100 increment & $0.115(0.134)$ \\
\hline \multicolumn{5}{|l|}{ Osmolarity } \\
\hline Mean $( \pm 95 \mathrm{Cl})$ & 44 & $323[315-331]$ & $1.25[0.98-1.60]$ per 10 increment & $0.078(0.076)$ \\
\hline \multicolumn{5}{|l|}{$\mathrm{pH}$} \\
\hline Mean $( \pm 95 \mathrm{Cl})$ & 63 & $7.13[7.09-7.16]$ & $0.68[0.44-1.04]$ per tenth increment & $0.074(0.063)$ \\
\hline Bicarbonates & & & & \\
\hline Mean $( \pm 95 \mathrm{Cl})$ & 47 & $9.7[8.2-11.2]$ & $0.92[0.80-1.05]$ per unit & $0.232(0.301)$ \\
\hline Ketones & & & & \\
\hline Mean $( \pm 95 \mathrm{Cl})$ & 15 & $5.4[3.9-7.0]$ & 1.15 [0.67-1.97] per unit & $0.614(0.325)$ \\
\hline Lactates & & & & \\
\hline Mean $( \pm 95 \mathrm{Cl})$ & 22 & $4.1[2.1-6.2]$ & $1.04[0.85-1.27]$ per unit & $0.705(0.602)$ \\
\hline$\beta-H B$ & & & & \\
\hline Mean ( $\pm 95 \mathrm{Cl})$ & 16 & $5.9[4.7-7.1]$ & $1.54[0.60-3.94]$ per unit & $0.369(0.052)$ \\
\hline Anion Gap & & & & \\
\hline Mean $( \pm 95 \mathrm{Cl})$ & 40 & 26.2 [23.5-28.9] & $1.05[0.97-1.14]$ per unit & $0.249(0.259)$ \\
\hline Acute Kidney Injury & & & & \\
\hline $\begin{array}{l}\text { Yes } \\
\text { No }\end{array}$ & 53 & $\begin{array}{l}23 \\
30\end{array}$ & $7.52(1.95-28.9)$ & $0.003(0.001)$ \\
\hline
\end{tabular}

+ Continuous variables

$\ddagger$ Discrete variables

* referring to patients with either T1D or T2D record

*** referring to patients with $\mathrm{T} 2 \mathrm{D}$ record

NA: not applicable 
medRxiv preprint doi: https://doi.org/10.1101/2021.01.10.21249550; this version posted January $14,2021$. The copyright holder for this preprint (which was not certified by peer review) is the author/funder, who has granted medRxiv a license to display the preprint in Figure 1. Study flow diagram It is made available under a CC-BY-NC-ND 4.0 International license .

312 records identified through database searching (174 in EMBASE, 138 in PubMed/Medline)

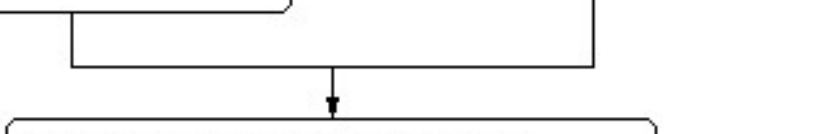

141 of records after duplicates removed

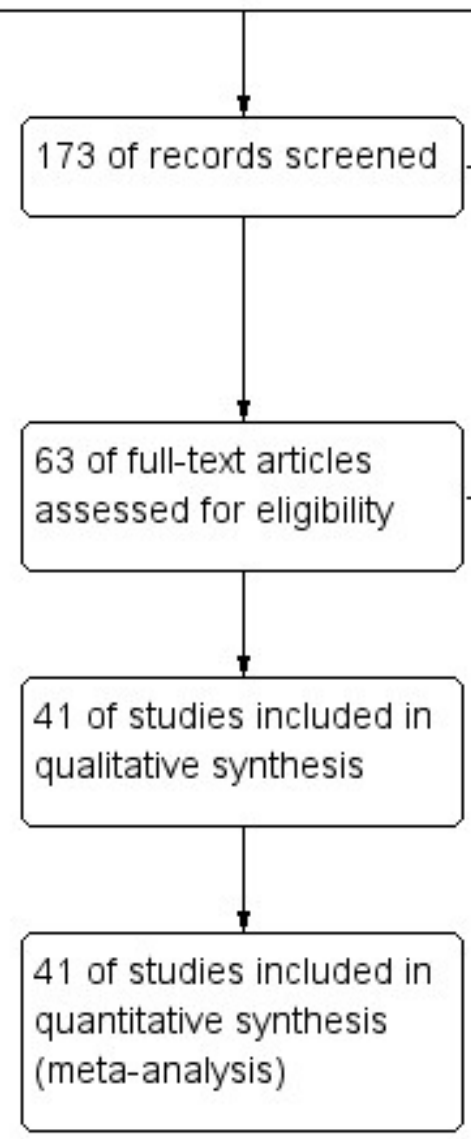


medRxiv preprint doi: https://doi.org/10.1101/2021.01.10.21249550; this version posted January 14, 2021. The copyright holder for this preprint (which was not certified by peer review) is the author/funder, who has granted medRxiv a license to display the preprint in

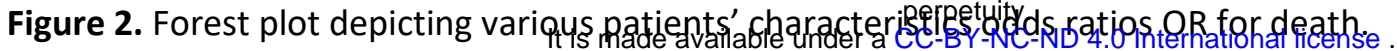

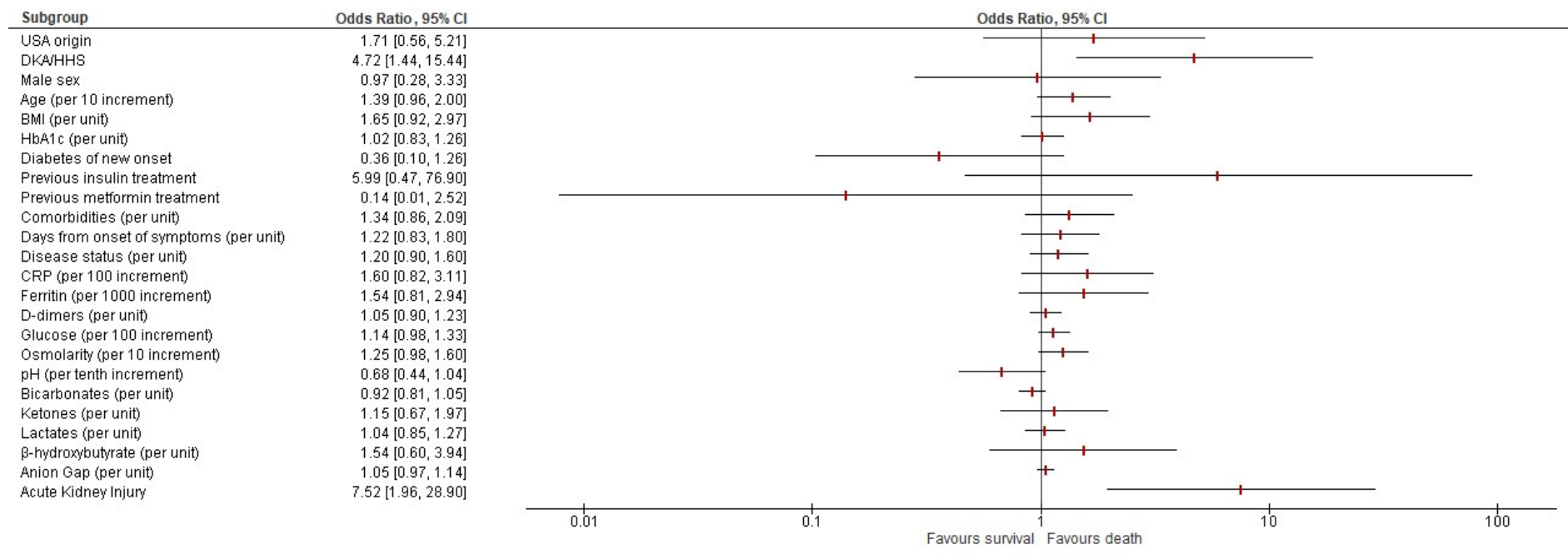




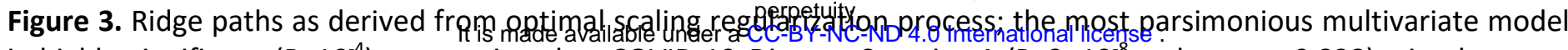
is highly significant $\left(P=10^{-4}\right)$, suggesting that COVID-19 Disease Severity $4\left(P=3 \bullet 10^{-8}\right.$, tolerance: 0.838$)$, simultaneous presence of DKA and HHS ( $P=0.021$, tolerance: 0.803$)$, and development of AKI ( $P=0.037$, tolerance: 0.788$)$ are all independently correlated with death.

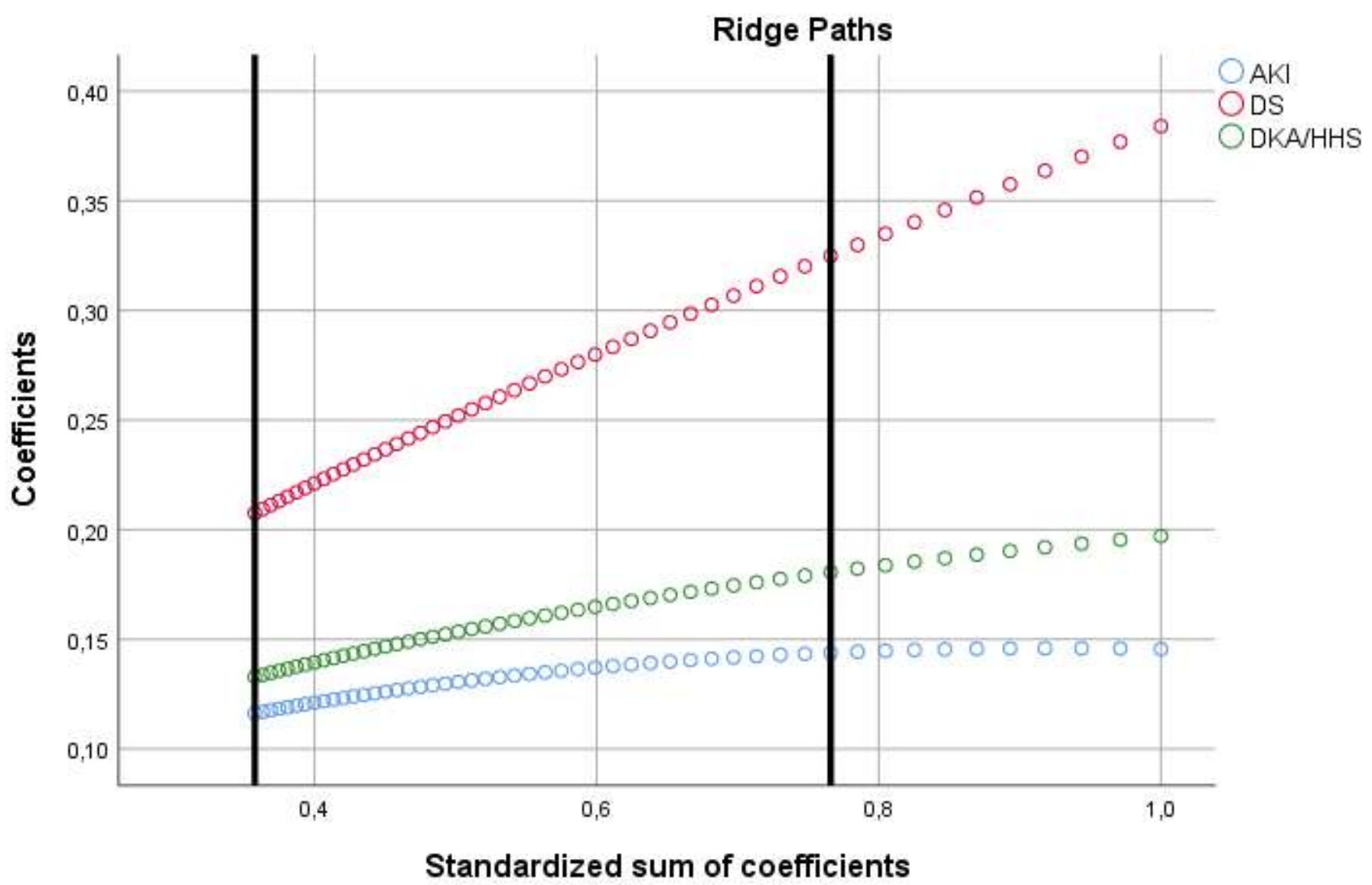

$\mathrm{X}$-axis reference lines at optimal model and at most parsimonious model within 1 Std. Error. 
medRxiv preprint doi: https://doi.org/10.1101/2021.01.10.21249550; this version posted January 14, 2021. The copyright holder for this

preprint (which was not certified by peer review) is the author/funder, who has granted medRxiv a license to display the preprint in SUPPLEMENTAL MATERIAL

It is made available under a CC-BY-NC-ND 4.0 International license.

\section{Disease status}

The disease-status (DS) of COVID-19 patients was classified based on the adaptation of the Sixth Revised Trial Version of the Novel Coronavirus Pneumonia Diagnosis and Treatment Guidance, as described previously [25]. Mild cases (DS1) were defined as mild clinical symptoms (fever, myalgia, fatigue, diarrhea) and no sign of pneumonia on thoracic X-Ray or/and CT scan. Moderate cases (DS2) were defined as clinical symptoms associated with dyspnea and radiological findings of pneumonia on thoracic X-Ray or/and CT scan, and requiring a maximum of $3 \mathrm{~L} / \mathrm{min}$ of oxygen. Severe cases (DS3) were defined as respiratory distress requiring more than $3 \mathrm{~L} / \mathrm{min}$ of oxygen and no other organ failure. Critical cases (DS4) were defined as respiratory failure requiring mechanical ventilation, shock and/or other organ failure that require an intensive care unit (ICU).

\section{Data synthesis and statistical analysis}

As variability values associated to each study were lacking, neither data synthesis nor classical meta-regression was applicable for case reports. Therefore, our option was to use classical regression without weighing each data point; this procedure still offered the advantage of a useful insight in cases that values were not too spread, despite that precise estimations could not be achieved. Thus, univariate analysis was performed to assess potent correlations of independent variables (study origin, presence of combined DKA/HHS, age, BMI, HbA1c, previously administered antidiabetics, comorbidities, days from onset of symptoms, DS, CRP, ferritin, d-dimers, glucose, osmolarity, arterial pH, bicarbonates, ketones, lactates, $\beta-\mathrm{HB}$, anion gap, AKI) with outcome (survival/discharge or death), which was considered as dependent variable, with the aid of binary regression. At a next step, multivariate analysis was performed with binary logistic regression over discretized, imputed, and regularized data; outcome was considered as a dependent variable, while all variables that reached a level of statistical significance $<0.10$ in the univariate analysis were treated as potent independent ones (the probability for stepwise entry and removal were set to 0.05 and 0.10 accordingly, the classification cutoff was set to 0.5 and the maximum number of iterations was set to 20). During this process, ridge regression was used to avoid model overfitting, tolerate large variances and overcome collinearity obstacles, all at the least possible additive bias; all variables of interest, if not already binary, were transformed to binary ones through nominal optimal scaling along with discretization to two groups, imputing of missing data was added, and 10-fold crossvalidation was selected through Optimal Scaling procedure (SPSS CATREG option). Models including parameters with tolerance $<0.67$ (variance inflation factor $>1.5$ ), as deduced from corresponding linear regression analysis assessing numerical values to outcome, were rejected to avoid collinearity. Imputed data tolerated missing values at a maximum of $25 \%$ for the entire model. Univariate comparisons were performed with the use of Pearson's $\chi^{2}$ for discrete variables; Fisher's exact test was alternatively preferred in case that expected frequencies were $<5$ in more than one cell. Kappa statistics were used for the evaluation of inter-rater agreement between authors. The level of statistical significance was set to $p=0.05$; values of $0.05 \leq p \leq 0.1$ were considered as needed further evaluation. Means are accompanied by their $95 \%$ confidence intervals $(\mathrm{Cl})$. All numerical values are given with at least two significant digits. Statistical analysis was performed with the use of IBM SPSS Statistics software, version 26.0.0.0, for Windows (IBM Corp (C)) and MedCalc ${ }^{\circledR}$ Statistical Software version 19.6 (MedCalc Software Ltd, Ostend, Belgium; https://www.medcalc.org; 2020). The 
medRxiv preprint doi: https://doi.org/10.1101/2021.01.10.21249550; this version posted January $14,2021$. The copyright holder for this

preprint (which was not certified by peer review) is the author/funder, who has granted medRxiv a license to display the preprint in

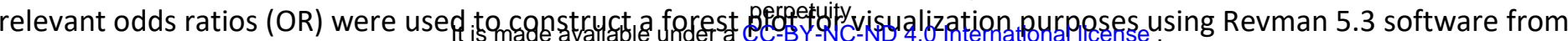
the Cochrane Collaboration [30].

\section{Supplemental Tables}

Supplemental Table 1. Case report studies excluded in the present meta-analysis $(n=3)$.

\begin{tabular}{|c|c|c|c|c|c|c|c|c|c|c|c|c|c|c|c|c|c|c|c|c|c|c|c|c|}
\hline Study & Origin & EP & Sex & Age & BMI & $\mathrm{HbA}_{1} \mathrm{C}$ & $\begin{array}{l}\text { DM } \\
\text { rec }\end{array}$ & $\begin{array}{l}\mathrm{DM} \\
\text { medication }\end{array}$ & $\begin{array}{l}\text { Comorbidi } \\
\text { ties }\end{array}$ & Day & DS & CRP & Ferr & $\mathrm{DD}$ & Glu & Osm & $\mathrm{pH}$ & Bic & Ket & Lac & $\begin{array}{l}\beta- \\
H B\end{array}$ & AG & AKI & $\begin{array}{l}\text { Outco } \\
\text { me }\end{array}$ \\
\hline Naguib & USA & DKA & $F$ & 8 & $?$ & 12.0 & No & $(-)$ & $(-)$ & $?$ & 1 & 241 & 715 & 1.0 & 429 & 284 & 7.30 & 14.0 & $?$ & $?$ & $?$ & $?$ & No & Dis \\
\hline Ozer [78] & Turkey & EDKA & $\mathrm{F}$ & 42 & $?$ & $?$ & Yes & $\begin{array}{l}\text { MET/1000, } \\
\text { EMP/10 }\end{array}$ & T2D, AH & ? & 4 & ? & $?$ & $?$ & 196 & $?$ & 7.08 & 8.9 & $?$ & $?$ & $?$ & 20 & No & Dis \\
\hline Machron & UK & DKA & $F$ & 28 & $?$ & 12.9 & Yes & $?$ & T1D & $?$ & 1 & 35 & $?$ & $?$ & 401 & $?$ & 7.00 & 3.2 & 3.8 & $?$ & $?$ & $?$ & No & Dis \\
\hline
\end{tabular}

EP: endpoint; BMI: body mass index; DS: disease severity; CRP: C-reactive protein; DD: d-dimers; Osm: serum osmolarity; Bic: arterial blood bicarbonate; Ket: arterial blood ketones; $\beta$-HB: beta-hydroxybutyrate; AG: anion gap; AKI: acute kidney injury; EDKA: euglycemic diabetic ketoacidosis; MET: metformin; EMP: empagliflozin.

\section{Supplemental References}

S1. Naguib MN, Raymond JK, Vidmar AP. New onset diabetes with diabetic ketoacidosis in a child with multisystem inflammatory syndrome due to COVID-19. J Pediatr Endocrinol Metab. 2020 Nov 12:/j/jpem.ahead-of-print/jpem-20200426/jpem-2020-0426.xml. doi: 10.1515/jpem-2020-0426. Epub ahead of print. PMID: 33180050.

S2. Marchon KA, Nunn MO, Chakera AJ. Images of the month: An incidental finding of spontaneous pneumomediastinum (Hamman's syndrome) secondary to diabetic ketoacidosis during the coronavirus pandemic. Clin Med (Lond). 2020 Nov;20(6):e275-e277. doi: 10.7861/clinmed.2020-0739. PMID: 33199339; PMCID: PMC7687302. 